\title{
LABARGA, Fermín. La Santa Escuela de Cristo
}

Biblioteca de Autores Cristianos. Madrid, 2013, 888 pp.

Dentro de la Historia de las Mentalidades en la España barroca, en 1653 surge una institución fundada en Madrid por Juan Bautista Ferruzzo, con un claro componente espiritual y con una nueva perspectiva en este campo, que rápidamente se extendió por todo el ámbito hispano, llegando su proyección a más de cuatrocientos pueblos y ciudades. En dicha institución, bajo la inspiración de San Felipe Neri, clérigos y varones laicos intentaban alcanzar una perfección espiritual mediante actos de piedad colectiva, sin manifestaciones externas, a través de la oración, la frecuencia sacramental y la puesta en práctica de las virtudes cristiana. A pesar de la gran repercusión que alcanzó en su momento, la Santa Escuela de Cristo es en la práctica poco conocida, salvo algunos artículos en revistas especializadas o referencias, más o menos, amplias en tesis doctorales relacionadas de alguna manera con la espiritualidad.

Así, el doctor en Teología y Filosofía y Letras (Historia) Fermín Labarga, profesor de Historia de la Iglesia Moderna en la Facultad de Teología de la Universidad de Navarra, con este estudio rescata del olvido, poniéndola al día, a esta institución, que pervive en la actualidad como Instituto Orgánico de las Santas Escuelas de Cristo.

El autor, tras una intensa tarea investigadora a través de fuentes manuscritas e impresa, así como de una amplia bibliografía específica sobre la propia institución y los hermanos que a ella pertenecieron en distintos momentos, entre ellos, Miguel de Molinos, Nicolás Antonio, Domingo Sarrió, Juan de Palafox, Francisco Valero y Losa, Nicolás María Alberca, Diego José de Cádiz, Andrés Humberto Fournet y Antonio María Claret, entre otros; nos ubica en sus orígenes en los que se aleja de las manifestaciones espirituales externas barrocas, para adentrase en el recogimiento interior de su miembros.

Fermín Labarga nos lleva de la mano desde el momento en que se instaura en España de la mano del ya citado Ferruzzo, con la intención de difundir la línea espiritual de San Felipe Neri y a imitación de su Oratorio, viéndose potenciada por la incorporación del que después sería beato, Juan de Palafox, obispo, primero, de Puebla de los Ángeles (México), y después de Osma; hasta la decadencia de esta institución en el siglo XIX y su intento de revitalización con motivo de III Centenario de su fundación y la erección del Instituto Orgánico de las Santas Escuelas de Cristo. 
El autor, tras exponer la rápida expansión en menos de veinticinco años, con la promulgación de sus Constituciones en 1656; la relación entre las distintas Escuelas del mapa hispano; la asistencia en hospitales, cárceles y ajusticiados; su proyección hacia los Virreinatos americanos; su organización interna; se centra en los requisitos que debían reunir los hermanos para pertenecer a la misma, ya fueran eclesiásticos o seglares, la condición social de estos últimos, hasta el punto de preguntarse si la Santa Escuela podría considerarse como una asociación con marcado carácter elitista, bajo un punto de vista social, económico o cultural. Por otro lado, el autor plantea interesantes aspectos no sólo sobre la vida interior que debía reinar en sus hermanos, sino también dentro de la vida cotidiana, así como la asistencia a espectáculos públicos y su comportamiento digno y fuera de escándalo. Tiene importancia, la atención que Labarga presta a aspecto constructivo del Oratorio, así como su emplazamiento, su distribución interna, imágenes y retablos en ellos. Así como, al ceremonial que en la Santa Escuela de Cristo se desarrollaba, e incluso a algunos de tipo externo que, aunque no estaban permitidos en sus Constituciones, haciendo caso omiso, se efectuaban en algunas de las Escuelas.

Con este trabajo, el profesor Labarga cruza el umbral de la Santa Escuela de Cristo, dándola a conocer con mayor profundidad, aproximándonos a una nueva visión de la espiritualidad barroca en los pueblos hispanos dentro del ámbito secular, mostrándonos un tema de gran interés fuera ámbito puramente relacionado con la Historia de la Iglesia.

Antonio Luis Galiano Pérez 